\title{
Viability of Islamic Insurance (Takaful) in India: SWOT Analysis Approach
}

\author{
Sheila Nu Nu Htay ${ }^{1} \&$ Syed Ahmed Salman ${ }^{1}$ \\ ${ }^{1}$ IIUM Institute of Islamic Banking and Finance, Kuala Lumpur, Malaysia \\ Correspondence: Syed Ahmed Salman, No.11, Jalan Bullion Mewah 12, Taman Bullion Mewah, Batu Caves, \\ Selangor 68100, Malaysia. E-mail: salmaniium@gmail.com
}

Received: July 1, 2013 Accepted: July 23, 2013 Online Published: August 27, 2013

doi:10.5539/res.v5n4p145 URL: http://dx.doi.org/10.5539/res.v5n4p145

\begin{abstract}
Takaful (Islamic insurance) has been widely accepted as an alternative to conventional insurance and offered in many Muslim and non-Muslim countries. The unique feature of Takaful is that is suitable and acceptable for anyone regardless of the religion to our surprise, Takaful has not been introduced in India. India has the third largest Muslim population after Indonesia and Pakistan and second largest population after China. In terms of economic development, India's GDP growth rate is $6.3 \%$ and it is expected that in coming years and it is believed that India will be one of the leading countries for the world economy. Thus, the objective is to examine the viability of Takaful in India by using SWOT analysis approach. Questionnaire has been distributed to both Muslim and non-Muslims to find out the awareness, acceptability, prospects and challenges of Takaful products. Interviews have been conducted to examine the opinions of ten insurance operators, fifteen Shari'ah advisors and five consultants regarding the prospects and challenges of introducing Takaful in India. The findings from 333 respondents show that awareness of Takaful is still at the minimum level. However, they are willing to participate if Takaful is offered in India. In addition, the findings of the interviews highlight that the Takaful has a good potential in India. However, it can be offered if the government supports it. Due to time limitation, the opinion of the regulators has not been examined and thus, future research should focus on it.
\end{abstract}

Keywords: Takaful, insurance, prospects, awareness, India and SWOT

\section{Introduction}

The entire history of the human race is full of exposure to misfortunes and adversities and the efforts attempted by the human being to mitigate these risks (Vaughan, 1997). Since in the earliest days, risk management has been practiced in Babylonian, Greek, Chinese, Phoenician, Indian, Egyptian, Arabs and Roman civilizations to protect their maritime and trade activities as well as for the provision of social safety nets for the communities (Vaughan, 1997; Mishra \& Mishra, 2007). In the modern time, one of the ways to manage the risks is through insurance.

Insurance as a risk transferred mechanism consists of the concepts and practices of interest, uncertainty and gambling. From the Islamic aspect, these elements are prohibited due to unfairness to the parties involved. Thus, the fatwa on prohibiting insurance has been issued by Muslim League Conference in Cairo in 1965 and National Fatwa Committee of Malaysia in 1972 and OIC Fiqh Academy in 1985 gradually. As an alternative contract, Islamic insurance (Takaful) has been proposed. Takaful is developed based on the concept of mutual help and cooperation while avoiding the prohibited elements in Islam. It is designed to fulfill the needs of both Muslims and non-Muslims and to protect all the involved parties in the case of misfortune.

According to the World Takaful Report 2010, if worldwide development of Takaful industry is considered, the total amount of contribution has gradually increased from US\$3.0 billion in year 2007 to US\$8.9 billion in year 2010. Thus, it can be considered that Takaful is one of the fastest growing areas of International finance. It is growing remarkably fast not only in Gulf but also in non -Muslim countries. The global Takaful industry with its modest beginnings in the early eighties with less than 10 players worldwide is now churning a multi-billion dollar business spanning across South-East Asia, Middle East, Africa, Central Asia and Europe with more than 200 players. 
Since Takaful has been widely spread to non-Muslim countries in addition to the Muslim countries, the researchers are motivated to forecast what future of Takaful looks like in India. There are several other reasons why this study focuses on Takaful in India by using SWOT analysis approach. Firstly, India is a country with third largest Muslim population (Pavithra, 2008). Secondly, in terms of economic growth, its GDP rate is 6.3\%. Thirdly, when the history of insurance in India is looked back, it started in 1818. At the beginning of the nineteenth century, insurance company mushroomed. The year 2000 can be considered as turning point in the events of insurance in India. After 50 years of state monopoly, the market was to private insurers. Thus, India life insurance market billowed from US\$9 billion in gross premium in 2000 to US\$52 billion in 2007. At the end of 2010-11, the numbers of insurance companies arose to 48 comprising of 23 life insurers, 24 non-life insurers and a re-insurer (IRDA, Annual report, 2010-11). It can be summed that India has large Muslim population with higher GDP growth rate and insurance revenue. In addition, offering the Takaful can penetrate new markets by the existing insurance operators. However, to the extent of researchers' knowledge, there is no research has been done on Takaful in India. Thus, the objective of this research is to investigate the viability of introducing Takaful in India by using SWOT analysis approach.

This research paper is organized in 5 sections. The second section discusses the most relevant literature. The third section mentions the methodology employed in this study. The fourth section elaborates on findings and the last section concludes.

\section{Literature Review}

\subsection{History of Insurance}

The first recorded 'modern' insurance contract was executed in Genoa in the $13^{\text {th }}$ Century and the first printed book on insurance was published in 1552 called, "On Insurance and Merchants" by Pedro de Santeram. Coleman's (1980) observations from the history of insurance indicate strong evidence that the insurance mechanism originated in financial arrangements between the bankers and borrowing merchants. Their loans on marine shipments are based on two conditions i.e. one requiring repayment of the loan with interest, the other requiring repayment of the loan with higher interest only if the voyage is successful (otherwise known as bottomry contracts/bonds).

In consonance with the development and sophistication of the global economic and financial markets, the insurance industry has undergone significant metamorphosis through greater convergence with the financial and capital markets. This results in innovative solutions in the form of the Alternative Risk Transfer (ART) products and carriers such as catastrophic bonds (CAT Bonds), captives, financial reinsurance and insurance derivatives (Culp, 2005). Insurance as a risk management tool has reached its pinnacle in meeting the challenges and expectations of the fast changing global economic and financial landscape.

\subsection{Definition, Concept and Principles of Insurance}

In the words of Ivamy (1970) the definition of an insurance contract is expressed as,

"A contract of insurance in the widest sense of the term may be defined as a contract whereby one person called the insurer undertakes in return for the agreed consideration called the premium, to pay to the other person called the assured, a sum of money or its equivalent on the happening of a specified event".

The concept of insurance allows the insured to substitute a small definite financial cost (the insurance premium) for a large but uncertain financial loss (the sum insured). This is supported by Crockford (1987) who describes insurance as an act to spread cost of risk among the insuring population whereby each individual insured enjoys the protection against the possibility of loss of an unknown size against a known cost (the insurance premium). This denotes that through the mechanism of insurance, uncertainty is reduced and losses are distributed among the exposure units. Insurance law has also stipulated special legal principles unique to the nature of insurance business. They are are aimed to ensure that insurance contracts are free from elements of profiteering from the losses insured against (Mishra \& Mishra, 2007; Merkin,2010).

The nature of insurance business involves public funds and it is a critical component of a country's financial engine. Thus, this industry is highly regulated in most countries. In the case of Malaysia for example, Bank Negara Malaysia (BNM) is the regulatory authority for both the insurance, reinsurance, Takaful and Re-Takaful industries under the purviews of the Insurance Act 1996 and the Takaful Act 1984 respectively. Apart from the local/domestic regulatory framework, the proposed Solvency II for example, provides a framework which is premised on a risk-based solvency standard for the global insurance industry. Its purpose is to increase the protection of policyholders by creating incentives for good risk management and optimal capital in tandem with the insurers' risks exposures. 


\subsection{Origin, Concept and Definition of Takaful}

\subsubsection{Origin of Takaful}

The insurance idea was conceptualized prior the time of the Holy Prophet Mohammed (s.a.w.) and it has been practiced until the starting of the $19^{\text {th }}$ century, when a Hanafi lawyer Ibn Abidin $(1784-1836)$ became the primeval Islamic philosopher. He has come up with the importance, general notation or idea and legal basis of an insurance agreement and he has been recognized as respected Abu Hanifa as its divine leader (Klingmuller, 1969).

\subsubsection{Concept of Takaful}

The general idea of Takaful welcomes the elements of mutual protection and shared liability among the participants. It adopts the concept 'Aqilah' during the Prophet's (s.a.w) time. Aqilah is nothing but payment of blood money or diyyah under the Arab tribal custom (Engku Rabiah \& Hassan Scott, 2008). During the ancient periods, Arab tribes followed a practice called 'Aqilah'. For example, if any associate of the tribes was murdered by a member of another tribe, the heir of the victim would be paid an amount of blood money as indemnity by the close kin of the murderer. Those close kin of the killer known as 'Aqilah and they are supposed to pay blood money (Billah, 2003).

The practice of Aqilah during the early Arab tribes shows the evidence of the arrangement of financial contribution on behalf of the murderer to pay indemnity to the heir of the victim. Such willingness is to create monetary contribution that should be equivalent to the premium in insurance practice. On the other hand, the compensation re-cooped under at Aqilah should be equivalent to the compensation of present insurance practices as it is a type of financial security for the heir against an unpredictable death of the prey or victim.

\subsubsection{Definition of Takaful}

The term Takaful is defined by an Arabic term which means joint guarantee or guaranteeing each other (Mahmoud, 2008). It stems from the Kafala that means to take care of one's needs. Takaful is a network of Islamic insurance based on the principle of Ta'awun (mutual cooperation) and Tabaru where the risk is shared collectively by members of a policy holder (Usmani, 2007). Takaful settlement adopts the elements of mutual cooperation, shared liability and joint indemnity among the certificate holders through the formation of a common pool subscribed out of their assets as contribution (Zuriah \& Redzuan, 2009). According to the AAOIFI's Accounting, Auditing and Governance Standards for Islamic Financial Institutions (2004/2005), Takaful is defined as "a system through which the participants donate part or all of their contributions which are used to pay claims for damages suffered by some of the participants. The company's role is restricted to managing the insurance operations and investing the insurance contributions."

\subsection{Takaful Models}

Contemporary Islamic scholars have recommended that the most suitable contracts to be applied in the management of a Takaful business are generally based on three concepts, namely; al-mudharabah or al-wakalah or al-waqf or a combination of the three contracts. There are studies by jurists and researchers to employ other contracts like al-wadiah. This has yet to be fully explored. The three models are briefly explained below.

\subsubsection{Takaful Based on Al-Mudharabah Model}

Al-Mudharabah (trustee profit-sharing) is defined as a contractual agreement between the provider of capital (sahibul mal) and the entrepreneur (mudharib) for the purpose of a business venture whereby both parties agree on a pre-determined profit-sharing ratio, whereas losses of the venture will be the sole responsibility of the capital provider except for losses due to the negligence, misconduct, violation of conditions by the entrepreneur (Ayub, 2007).

The principle of mudharabah when applied to the Takaful contract defines the Takaful operator as the entrepreneur who undertakes the Takaful business activities and the participants entrust funds to the Takaful operator by means of Takaful contributions. The Takaful contract may specify (in some model) the proportion of profit (surplus) to be shared between the participants and the Takaful operator (Aznan, 2011).

\subsubsection{Takaful Based on Al-Wakalah Model}

The term "wakalah" is a noun of the word 'wakala' which means performing tasks on behalf of others, delegation of a task or job to another, and in English it generally means agency. The AAOIFI Shari'ah Standard No. 23 defines wakalah as, "The act of one party delegating the other to act on its behalf in what can be the subject matter of delegation". 
Under Takaful, this model entails the operator (the wakeel) to manage the Takaful fund as an agent of the participants and is paid an upfront fee (the ujrah) for his-services. Profit and losses from the management of the Takaful fund belong entirely to the participants, unless the losses were due to the negligence or misconduct of the Takaful operator.

\subsubsection{Takaful Based on Al-Waqf model}

Waqf literary means, 'detention' but its legal meaning is, 'the dedication of a property or giving it away in charity for a good purpose and other religious, pious or charitable purposes. The establishment of waqf according to Abdul Rahman (2007) extinguishes the right of the waqif (dedicator) and transfer its ownership to Allah (swt). For Takaful under this model, a waqf account has to be established by the operator within the Takaful fund. To this effect, the operator is required to relinquish some kind of "seed" money as waqf to operationalize the said waqf fund. The Waqf fund shall work to extend financial assistance to its members in the event of losses and to extend benefits to its members strictly in accordance with the Waqf Deed. All the expenses related to the underwriting and operational cost of Takaful shall be charged to the Waqf fund. As manager, the Takaful operator will perform all functions necessary for the operations of the Waqf against a Wakala fee to be deducted from the contribution paid by the participants.

\subsubsection{Takaful Based on Hybrid Model}

This business model is a combination of the two principles of al-mudharabah and al-wakalah. Under this model, a relationship between the operator which combines the role of entrepreneur or mudharibas well as the agent or wakeel of the participant, whilst the latter in the capacity as both provider of capital or sahibul-mal and principal to the agent. By this arrangement, the operator will receive the agency fee as upfront charges from the Takaful fund in addition to sharing the profit generated from the investment of the Takaful fund in accordance with the al-mudharabah contract.

\subsection{Types of Takaful Contract}

\subsubsection{General Takaful}

General Takaful offers protection on a temporary basis, usually protecting a time of one year. It generally gives protection for material goods, loss or injure, legal responsibility happening from injury caused by the assured to a third party and unforeseen death or damage to a third party. There are various types of general Takaful products ranging from motor and life to marine engineering, aviation and transport Takaful. Furthermore, there are other regular general Takaful products arising from employer's liability Takaful, burglary Takaful to contract work Takaful. General Takaful donations given by contributors as tabarru' is utilized under the concepts of Wakalah and Mudarabah (Azman Ismail, 2013).

\subsubsection{Family Takaful}

Family Islamic Insurance (Takaful) businesses are agreements which are long-term in nature. It generally gives cover of joint assistance to participants in the form of monetary benefits from a defined fund in the case of any misfortune, disaster or bad luck. The family Takaful plan offers protection and the platform for investments to participants (Ezamshah, 2011).

\section{Data, Sample, Sampling Method, Statistical Method and Research Approach}

Literature provides the evidence that India is one of the countries where Takaful industry has potential in future due to its economic growth and Muslim population. However, until now, Takaful has not been introduced yet. This research makes an initiative to explore on the potential of Takaful market in India. This study follows the SWOT analysis approach to find out the viability of takaful in India. Since the research is an exploratory study, the primary data such as the questionnaire and interviews are used. The purpose of distributing questionnaire is to examine the perception Muslims and Non-Muslims towards awareness, acceptability, prospects and challenges of Takaful in India. In addition, Shari'ah advisors, consultants and insurance operators contacted in order to know the strengths, weaknesses, opportunities and threats that might be faced if Takaful is introduced in India. Secondary data includes various articles, books, journals that will contribute in drafting out a comprehensive picture about the possibilities, challenges and prospects of Takaful in India. Quota sampling method is adopted and Sekaran and Bougie (2010) recommends this sampling method for the exploratory research. Descriptive statistics is adopted. 


\section{Findings}

\subsection{Profile of the Respondents}

Table 1. Profile of the respondents

\begin{tabular}{|c|c|c|c|c|c|c|}
\hline \multirow[t]{2}{*}{ Questions } & \multicolumn{2}{|l|}{ Muslims } & \multicolumn{2}{|c|}{ Non-Muslims } & \multicolumn{2}{|l|}{ Overall } \\
\hline & Frequency & Percentage & Frequency & Percentage & Frequency & Percentage \\
\hline \multicolumn{7}{|c|}{ Gender of the respondent } \\
\hline Male & 135 & 62.5 & 66 & 56.4 & 201 & 60.4 \\
\hline Female & 81 & 37.5 & 51 & 43.6 & 132 & 39.6 \\
\hline \multicolumn{7}{|l|}{ Respondent's Age } \\
\hline $18-30$ & 32 & 14.8 & & & 32 & 9.6 \\
\hline $31-40$ & 84 & 38.9 & 33 & 28.2 & 117 & 35.1 \\
\hline $41-50$ & 56 & 25.9 & 58 & 49.6 & 114 & 34.2 \\
\hline $51-60$ & 35 & 16.2 & 26 & 22.2 & 61 & 18.3 \\
\hline Others & 9 & 4.2 & & & 9 & 2.7 \\
\hline \multicolumn{7}{|c|}{ Respondent's Education Background } \\
\hline Below degree & 34 & 15.7 & 9 & 7.7 & 43 & 12.9 \\
\hline Degree & 62 & 28.7 & 18 & 15.4 & 80 & 24.0 \\
\hline Diploma & 39 & 18.1 & 36 & 30.8 & 75 & 22.5 \\
\hline Masters & 63 & 29.2 & 37 & 31.6 & 100 & 30.0 \\
\hline $\mathrm{PhD}$ & 18 & 8.3 & 17 & 14.5 & 35 & 10.5 \\
\hline \multicolumn{7}{|c|}{ What is your religion? } \\
\hline Hindu & & & 85 & 72.6 & 85 & 25.5 \\
\hline Muslim & 216 & 100 & & & 216 & 65.1 \\
\hline Sikh & & & 21 & 17.9 & 21 & 6.1 \\
\hline Christian & & & 11 & 9.4 & 11 & 3.3 \\
\hline Others & & & & & & \\
\hline \multicolumn{7}{|c|}{ Occupation } \\
\hline Student & 11 & 5.1 & & & 11 & 3.3 \\
\hline Self- employed & 51 & 23.6 & 17 & 14.5 & 68 & 20.4 \\
\hline Private sector employee & 77 & 35.6 & 38 & 32.5 & 115 & 34.5 \\
\hline Government sector employee & 71 & 32.9 & 51 & 43.6 & 122 & 36.6 \\
\hline Housewives/ Retried & 6 & 2.8 & 11 & 9.4 & 17 & 5.1 \\
\hline \multicolumn{7}{|c|}{ Personal Income } \\
\hline Below Rs 10,000 & 29 & 13.4 & 7 & 6.0 & 36 & 10.8 \\
\hline Rs $10,001-20,000$ & 56 & 25.9 & 18 & 15.4 & 74 & 22.2 \\
\hline Rs $20,001-30,000$ & 60 & 27.8 & 38 & 32.5 & 98 & 29.4 \\
\hline Rs $30,001-40,000$ & 47 & 21.8 & 39 & 33.3 & 86 & 25.8 \\
\hline Rs $40,001-50,000$ & 20 & 9.3 & 15 & 12.8 & 35 & 10.5 \\
\hline More than 50,000 & 4 & 1.9 & & & 4 & 1.2 \\
\hline
\end{tabular}

In India, there are 28 states. Hyderabad, Bangalore and Kerala are chosen for the study as it has Muslim population. Total of 500 questionnaires are distributed to Muslims and Non-Muslims equally. Out of 250 questionnaires distributed to Muslims, 216 people response the questionnaire and hence, the respond rate for the Muslims is $86 \%$. In the case of non-Muslims, out of 250 questionnaires distributed, only 117 responded and thus, the respond rate from non-Muslims is $47 \%$. Therefore, overall respond rate is $67 \%$. When the gender of the respondents is examined; most of the respondents are male since $60.4 \%$ belong to the male. It might be due to the fact that targeted group is working people and according to the Indian culture, majority of the working people are male. The age range of the majority of respondents is between 31 to 50 years and $69.3 \%$ of the respondents belong to it. When the education background of the respondent is examined, most of them are master degree holders, followed by degree, diploma, non- degree and Ph.D. holders (refer to Table 1).

In the case of religion, highest percentage of the respondents is Muslims (65.1\%) and second highest respondent group were Hindus (25.5\%). The employment status showed that $36.6 \%$ were in government section, $34.5 \%$ in 
private section, $20.4 \%$ were self-employed, $5.1 \%$ were retirees and $3.3 \%$ were student. As most of the respondents are employed, income for the majority is between Rs.10, 001 and Rs. 40,000.

4.2 Findings on Awareness of Takaful

Table 2. Awareness of Takaful

\begin{tabular}{|c|c|c|c|c|c|c|c|}
\hline \multirow[t]{2}{*}{ Questions } & & \multicolumn{2}{|l|}{ Muslims } & \multicolumn{2}{|c|}{ Non-Muslims } & \multicolumn{2}{|l|}{ Overall } \\
\hline & & Frequency & Percentage & Frequency & Percentage & Frequency & Percentage \\
\hline Q1. Have you heard & Yes & 91 & 42.1 & 34 & 29.1 & 125 & 37.5 \\
\hline about Islamic Insurance & No & 125 & 57.9 & 83 & 70.9 & 208 & 62.5 \\
\hline Q2. Are you aware that & Yes & 86 & 39.8 & 8 & 6.8 & 94 & 28.2 \\
\hline conventional insurance & No & 24 & 11.1 & 25 & 21.4 & 49 & 14.7 \\
\hline $\begin{array}{l}\text { products are not Shari'ah } \\
\text { compliance? }\end{array}$ & $\begin{array}{l}\text { Not } \\
\text { sure }\end{array}$ & 106 & 49.1 & 84 & 71.8 & 190 & 57.1 \\
\hline Q3. Do you know the & Yes & 97 & 44.9 & 8 & 6.8 & 105 & 31.5 \\
\hline involvement of Interest, & No & 16 & 7.4 & 16 & 13.7 & 32 & 9.6 \\
\hline $\begin{array}{l}\text { uncertainty and } \\
\text { gambling make the } \\
\text { conventional insurance } \\
\text { non-Shari'ah compliant? }\end{array}$ & $\begin{array}{l}\text { Not } \\
\text { sure }\end{array}$ & 103 & 47.7 & 93 & 79.5 & 196 & 58.9 \\
\hline Q4. Do you know the & Yes & 44 & 20.4 & - & - & 44 & 13.2 \\
\hline Shari'ah principles & No & 39 & 18.1 & 8 & 6.8 & 47 & 14.1 \\
\hline $\begin{array}{l}\text { embedded in offering } \\
\text { Islamic insurance } \\
\text { (Takaful) products? }\end{array}$ & $\begin{array}{l}\text { Not } \\
\text { sure }\end{array}$ & 133 & 61.6 & 109 & 93.2 & 242 & 72.7 \\
\hline Q5. Are you aware that & Yes & 21 & 9.7 & & & 21 & 6.3 \\
\hline conventional insurance is & No & 76 & 35.2 & 67 & 57.3 & 143 & 42.9 \\
\hline $\begin{array}{l}\text { based on the concept of } \\
\text { "Contract of Exchange", } \\
\text { whereby Islamic } \\
\text { insurance (Takaful) is } \\
\text { based on the concept of } \\
\text { "Mutual cooperation } \\
\text { among the participants"? }\end{array}$ & $\begin{array}{l}\text { Not } \\
\text { sure }\end{array}$ & 119 & 55.1 & 50 & 42.7 & 169 & 50.8 \\
\hline Q6. Are you aware that & Yes & 22 & 10.2 & & & 22 & 6.6 \\
\hline in Islamic insurance & No & 71 & 32.9 & 82 & 70.1 & 153 & 45.9 \\
\hline $\begin{array}{l}\text { (Takaful), surplus or } \\
\text { profit distribution will be } \\
\text { made by the Islamic } \\
\text { insurance (Takaful) } \\
\text { operators, while in } \\
\text { conventional insurance; } \\
\text { the profit will be only } \\
\text { taken by the insurance } \\
\text { operators? }\end{array}$ & $\begin{array}{l}\text { Not } \\
\text { sure }\end{array}$ & 123 & 56.9 & 35 & 29.9 & 158 & 47.4 \\
\hline Q7. Are you agreeing & Yes & 92 & 42.6 & 50 & 42.7 & 142 & 42.6 \\
\hline that Islamic insurance & No & 10 & 4.6 & 24 & 20.5 & 34 & 10.2 \\
\hline $\begin{array}{l}\text { (Takaful) products are } \\
\text { offered not only to the } \\
\text { Muslims but also to the } \\
\text { non-Muslims? }\end{array}$ & $\begin{array}{l}\text { Not } \\
\text { sure }\end{array}$ & 114 & 52.8 & 43 & 36.8 & 157 & 47.1 \\
\hline Q8. Do you know that & Yes & 25 & 11.6 & 4 & 3.4 & 29 & 8.7 \\
\hline Islamic insurance & No & 66 & 30.6 & 70 & 59.8 & 136 & 40.8 \\
\hline $\begin{array}{lr}\text { (Takaful) } & \text { products } \\
\text { include } & \text { general }\end{array}$ & $\begin{array}{l}\text { Not } \\
\text { sure }\end{array}$ & 125 & 57.9 & 43 & 36.8 & 168 & 50.5 \\
\hline
\end{tabular}




\begin{tabular}{|c|c|c|c|c|c|c|c|}
\hline $\begin{array}{l}\text { insurance } \\
\text { insurance } \\
\text { similar to } \\
\text { simily } \\
\text { insurance? }\end{array}$ & & & & & & & \\
\hline Q9. Do you know that & Yes & 16 & 7.4 & & & 16 & 4.8 \\
\hline the protection coverage & No & 101 & 46.8 & 6 & 5.1 & 107 & 32.1 \\
\hline $\begin{array}{l}\text { of Islamic insurance } \\
\text { (Takaful) is same with } \\
\text { that of conventional } \\
\text { insurance? }\end{array}$ & $\begin{array}{l}\text { Not } \\
\text { sure }\end{array}$ & 99 & 45.8 & 111 & 94.9 & 210 & 63.1 \\
\hline
\end{tabular}

To examine the awareness of Takaful in India, respondents are asked to answer nine questions (refer to Table 2). $62.5 \%$ of the overall respondents had not heard of Takaful, $57.9 \%$ of the Muslims and $70.9 \%$ of the Non-Muslims were not aware about Takaful. Moreover, majority of the overall respondents $(57.1 \%)$ are not sure that conventional insurance is not Shari'ah compliant. Muslim respondents (49.1\%) and Non-Muslim respondents (71.8\%) are also not sure of the non-Shari' ah compliant nature of conventional insurance.

As for the reasons (such as the involvement of interest, uncertainty and gambling) why conventional insurance is non- Shari'ah compliant, majority of the overall respondents (58.9\%) is not sure why conventional insurance is not Shari'ah compliant. $47.7 \%$ of the Muslim respondents and $79.5 \%$ of the Non-Muslim respondents is not sure why conventional insurance is prohibited in Islam.

Takaful as an alternative to conventional insurance, Shari'ah principles have been embedded in it. However, overall, majority of the respondents (72.7\%) is not sure of it. In the case of Muslim and Non-Muslims, the percentages are $61.6 \%$ and $93.2 \%$ respectively. While the knowledge on the different concepts between the conventional and Takaful is asked, majority of the overall respondents $(50.8 \%)$ are not certain about the differences in terms of the concepts. In line with the overall respondents, Muslim respondents $(55.1 \%)$ and Non-Muslim respondents (42.7\%) are not sure of the different concepts, i.e. conventional insurance is based on the concept of "Contract of Exchange", whereby Islamic insurance (Takaful) is based on the concept of "Mutual cooperation among the participants".

Since Takaful is founded on the concept of mutual cooperation, the surplus (profit) will be distributed back to the participants by Takaful operators while this is not the practice in conventional insurance. However, majority of the respondents (47.4\%) are not sure of these different practices. $56.9 \%$ of the Muslim respondents are not sure while $70.1 \%$ of the Non-Muslim respondents do not know about this practice.

Takaful products are not meant only for the Muslims and however, majority of the overall respondents (47.1\%) is not sure of this. In the case of the Muslim respondents, $52.8 \%$ percentage is not sure and $42.6 \%$ of the Muslim respondents are aware that Takaful is not meant only for Muslims. Similarly, $42.7 \%$ of the Non-Muslims agree that Takaful products are to protect the misfortune of anyone who participates.

In spite of Takaful offering similar products as by conventional insurance, majority of the overall respondents $(50.5 \%)$ and Muslims (57.9\%) are not sure of it. 59.8\% of Non-Muslims do not know that Takaful can offer same products as conventional insurance. In the event of accidents or any misfortune, the coverage of Takaful can be the same with that of conventional insurance. However, majority of the overall respondents $(63.1 \%)$ and $94.9 \%$ of Non-Muslims are not sure on the coverage and $46.8 \%$ of the Muslim respondents do not know about the coverage. Based on the findings, it seems that the respondents' knowledge about Takaful is limited. Hence, it could be concluded that the future Takaful operators will face a big challenge to penetrate the market unless well-trained agents are able to educate the public in general and Muslims in particular to understand the advantages of Takaful over conventional insurance and the Shari'ah compliant nature of Takaful.

\subsection{Findings on Interview}

The findings on interview have been summarized after interviewing five experts and fifteen Shari'ah advisors who have experience in providing the consultancy and Shari'ah advisory service and ten insurance operators from India. Interview is conducted based on the SWOT analysis approach.

To find out the strength of the existing insurance operators, the interviewees are asked the possibility of offering Takaful products. All the interviewees collectively agreed it is possible to offer Takaful products by extending the product line and opening Takaful windows. Moreover, they highlighted the existing strength to offer Takaful products and they are as follows: 
1. Regarding the Takaful products, they will be able to offer general Takaful products which are alternative to current insurance products.

2. In the case of Muslim policy holders, they will most probably convert from conventional to Islamic insurance. Based on their experience in dealing with Muslim insurance holders, there are many Muslims who inquire about Takaful products as they are interested in participating.

3. For marketing, the existing agents can be trained to promote Takaful products, thus it should not be added burden for insurance operators.

4. Takaful products are not only limited to Muslim participants and hence, they might be able to attract the Non-Muslims to participate if Takaful products can offer better coverage.

5. There should not be much additional cost to insurance operators since the existing facilities and staff will be able to handle if the first stage of offering Takaful product is by extending the product line.

6. Since there are a quite few Takaful models currently used by the Takaful operators in other countries, it is easy for the insurance operators to adopt any existing suitable model without putting effort to come out with a new model.

7. Some of the existing staff is Muslims whose education background is Shari'ah and hence, there should not be any difficulty to find the Shari'ah advisors for approval of the Takaful products.

The possible weaknesses to offer the Takaful products highlighted by the interviewees are as follows:

1. Although the existing staff will be able to handle it, the training is necessary. Thus, the certain amount of cost will be incurred although it might not be significant.

2. There is a possibility that to certain extent there will be completion between insurance and Takaful products if they are offered by the same operators.

3. Since Takaful products must be Shari'ah compliant, the contribution received cannot be mixed with insurance income. Maintaining separate accounts is necessary and the staff should be aware of this issue.

4. It will be preferable if Muslim agents can promote Takaful products but based on the current employment, they needs to recruit more Muslim staff.

Moreover, all the interviewees collectively agreed that there are good opportunities to offer Takaful in India and they are summarized as follows:

1. Nowadays, takaful is growing rapidly and it is penetrating the market not only in the Muslim countries, but also in the non-Muslim countries. Some of the Muslim countries which are offering takaful products are Malaysia, Indonesia, Brunei and GCC countries while non-Muslim countries are Thailand, United Kingdom, Australia and United States of America. Thus, all the interviewees believe that India should welcome and offer it to take the advantage of its growth potential and to attract the Muslim investors.

2. The conventional insurance sector is the largest single contributor to the capital markets holding substantial financial presence in both the public and private sectors. Takaful operations can work as an alternative option and can provide an effective method to accumulate the savings of individuals for the collective good of the community.

3. In addition, Islamic Insurance is becoming a hot and sizzling sector in India and other parts of Asia, many institutes have started to provide Islamic Finance courses, Hyderabad-based Institute of Islamic Banking and Finance (IIBF) and Knowledge Network India Pvt. Ltd. (KNI), Gurgaon are among the few institutes which provide online Islamic Banking and Takaful Insurance Courses. Thus, it is possible that this might be the starting stage to offer the Takaful products later.

4. India has third largest Muslim population after Indonesia and Pakistan and second largest population after China. In addition, takaful is not meant for Muslims only but also for non-Muslims. Thus, by offering takaful, the insurance operators can expand their market share.

5. After September 11 attack, most of the Muslims are taking back their investments from U.S and Europe and looking for the sound economic environment. Fortunately, India is one of the leading countries of world economies and thus, if takaful is offered in India, it is believed that the Muslim investors will be interested to invest in it. 
6. Majority of the interviewees believe that India should take advantage on the economic downturn in the west, for instance Lehman Brothers. Due to the crisis, all the investors including both Muslims and non-Muslim are looking for the better investment choice in the South East Asia. One of the interviews says:

"In Malaysia, there are a few takaful and retakaful operators are foreign owned. It shows that how Malaysia is persuading foreign direct investment by opening up the takaful market".

7. Majority of the insurance operators have experience most of the Muslims are reluctant to buy the life insurance policy due to non-Shari'ah compliant. By offering takaful, the insurance operators can be more profitable, at the same time; it is given chance to the Muslims to save their money for the future needs and for emergency. It will consequently contribute to the growth of the Indian economy as a whole.

Despite the good opportunities, the potential threat to offer Takaful products is expressed by the interviewees. There are several key issues to be looked, but prime among them being the acceptability of Takaful terminology by Insurance Regulatory and Development Authority "IRDA" which is a supervisory body in India for Insurance and the insurance operators collectively agree that politics is the main threat

There is no doubt that takaful can be offered in India, however one main limitation is the term "takaful" itself. By hearing this name, non-Muslim misunderstand that this product is only for the Muslims. Thus, when insurance operators are offering takaful products, they need to know how to market the products by disseminating the right messages and the benefits of the products.

In sum, interview results show that strength and opportunity outweigh over weakness and threat. Hence, it could be concluded that there is a good prospect to offer Takaful products in India, in spite of some weakness and threat.

\section{Conclusion, Limitation, Contribution of the Study and Area for Future Research}

It has been known that Takaful has been introduced as an alternative to insurance not only in the Muslim countries but also in the non-Muslim countries. This study focuses the viability of introducing Takaful in India due to its large number of Muslim population in the world and GDP growth rate and expansion of insurance operators. SWOT analysis approach is adopted to examine the viability of Takaful. $72.4 \%$ of the total respondents are interested to participate in Takaful products. Apart from that, $97.2 \%$ of the Muslim respondents replied that if Takaful products are offered, they are willingly to switch from conventional insurance to Takaful.

From the interview, it has been found that, there is no doubt that a huge potential for Islamic Insurance in India exists, but, it will need some strong policy decisions to make it a reality. With a population of 156 million Muslims, India stands to gain tremendous advantages, by attracting around \$1trillionUS in Islamic investment funds from Gulf countries. This would help the national current account and keep the fiscal deficit in check. Islamic Insurance is at an incipient stage. Since the existing legal framework does not cover Islamic Insurance, a lot of amendments need to be carried out in the prevalent legal set up. Appropriate models need to be selected and implemented to suit society's diverse financial needs. Based on the above results, it could be summed that the prospects of introducing Takaful in India are more than the challenges that might be faced by the operators and it is viable to introduce Takaful in India.

The limitation of this research is that the questionnaire is only distributed in Hyderabad, Bangalore and Kerala not in all the states of India. Although this research has limitation, it is believed that these research findings will not be affected by the above stated limitation. It is because almost half of the respondents are Non-Muslims and these states have a mix of various ethnic groups, namely, Muslims, Hindus, Sikhs and Christians.

It is expected that the findings of this research will be of interest, especially to insurance operators, investors, regulators and public. Since Indian economy is booming, the current insurance operators should take advantages of it by extending their existing products and adding new products, i.e. Takaful products. Thus, it is expected that the findings of this research will be interest to by the insurance operators to strategize their business. It should be noted that although takaful products are Shari'ah compliant, it does not mean that takaful industry is totally free from any undesirable issues such as agency problems and solvency issues. Thus, we would like to suggest that if takaful products are offered in India, it is necessary to choose the takaful model which is suitable to the Indian market and learn the lessons from the countries like Malaysia which have experienced in offering takaful products.

From the aspect of the investors, it is expected that the findings will attract the attention of the investors since it is a new business opportunity for them to invest in the new industry, i.e. Takaful industry. In the case of the regulators, the results of this research show the demand for Takaful products in India and hence, it is expected that the regulators can use this finding to develop future rules and regulations. 
In future, the researchers should look at the regulators' perception towards introducing Takaful in India. In addition, the suitable Takaful model and products within the Indian operational and legal environment should be proposed by taking into consideration the opinions of current insurance operators and practices of other countries like Malaysia.

\section{References}

Abdul, R. I. D. (2007). Shariah: The Islamic law. Kuala Lumpur: A.S Noordeen.

Ayub, M. (2007). Understanding Islamic Finance. UK: John wiley and sons.

Azman, I. (2013). Legal and Shari'ah framework of Takaful in Malaysia.

Aznan, H. (2011). Fundamentals of Shariah in Islmic Finance. IBFIM. Kuala Lumpur.

Billah, M. (2003). Islamic and Modern Insurance principles and practices. Malaysia: Ilmiah Publishers.

Coleman, J. W. (1980). In R. W. S. Reinsurance (Ed.), The Pro Rate Treaty in Property Insurance. New York: The College of Insurance.

Crockford, N. (1987). The Administration of Insurance. England: ICSA Publishing Limited.

Culp, L. C. (2005). Alternative Risk Transfer. In M. R. M. Frenkel (Ed.), Risk Management Challenge andOpportunity. Berlin: Springer

Engku, R., \& Hassan, S. (2008). Essential guide to Takaful (Islamic insurance). Malaysia: CERT publications.

Ezamshah, I. (2011). Basic Takaful broking hand book. Malaysia: IBFIM.

IRDA, Annual (2010-2011). Report. Retrieved from http://www.irda.gov.in/admincms/cms/frmgenerallist.aspx?df=jrnl\&mi=15

Islamic Fiqh Academy, Resolutions and recommendations of the council of the Islamic Fiqh academy (1985-2000). Retrieved from http://www.scribd.com/doc/19237054/Resolutions-ofthe-Council-of-the-IslamicFiqh-Academy

Ivamy, E. R. (1970). General Principles of Insurance Law (2nd ed.). London: Butterworths.

Klingmuller, E. (1969). The concept and development of Insurance in Islamic Countries in Islamic culture (Vol. $3)$.

Mishra, S. M. N. (2007). Insurance Principles and Practice. New Delhi: S.Chand \& Co.

Merkin, R. (2010). Collinvaux Law of Insurance. Sweet \& Maxwell.

Mahmoud, H. (2008). Insurance: Takalful gaining ground the actuary.

Pavithra, G. (2008). Islamic Banking in India: status, prospects and recommendations. Retrieved from http://www.crisil.com/crisil-young-thoughtleader 2008/dissertations/Dissertation_GPavithra.pdf

Sekeran, U., \& Bougie, R. (2010). Research method for business: skin building Approach (5th ed.). UK: John wiley and son ltd.

Usmani, M. J. (2007). Takaful paper presented at securities and exchange commission of Pakistan. Takaful conference in Karachi.

Vaughan, E. J. (1997). Risk Management. John Wiley \& Sons.

Zuriah, A. R., \& Hendon, R. (2009). Takaful 21st century Insurance Innovation. Malaysia: Mc Graw Hill.

\section{Copyrights}

Copyright for this article is retained by the author(s), with first publication rights granted to the journal.

This is an open-access article distributed under the terms and conditions of the Creative Commons Attribution license (http://creativecommons.org/licenses/by/3.0/). 